Paper published in Social Indicators Research, 3 January 2021

The free-view version of the publication is available at: $\underline{\mathrm{https}: / / \mathrm{rdcu} \cdot \mathrm{be} / \mathrm{ccOVQ}}$

To cite this article: Gibrán Cruz-Martínez (2021): Mapping Welfare State Development in (post) Neoliberal Latin America, 157, pp. 175-201. https://doi.org/10.1007/s11205-020-

$\underline{02575-6}$

\title{
Mapping Welfare State Development in (post) Neoliberal Latin America
}

\author{
Gibrán Cruz-Martínez \\ Institute of Public Goods and Policies, CSIC \\ gibran.cruz@csic.es
}

\begin{abstract}
Why have some countries in Latin America and the Caribbean developed more comprehensive welfare systems than others? Do political and economic factors help us signal the (un) favourable paths taken by countries with different degrees of welfare state development in the XXI century? This paper addresses limitations of previous comparative research to continue (re) searching the conditions of welfare state development. A composite multidimensional welfare state development index (WeSDI) is constructed for 18 countries between 2000-2015. The four dimensions are the magnitude of social expenditure, the scope of coverage of welfare programmes, quality of the coverage of welfare programmes and outcomes of welfare institutions. The WeSDI uses goalposts (i.e. natural zeros and aspirational targets) to normalise individual indices and avoid the "relativity problems" of results. We use crisp-set Qualitative Comparative Analysis to test how necessary and/ or sufficient eight political and economic conditions are (alone or in combination) to foster multidimensional welfare state development in the region. The causal conditions are openness to external shocks, debt obligations, revenue-collection capabilities, labour movement strength, strength of the left, policy legacies of welfare institutions, size of the outsider population and quality of democracy. The paper confirms the relevance of democratic strength, and revenue-collection capabilities as sufficient conditions of the highest levels of welfare state development in the (post) neoliberal era. In addition to labour movement strength, these same economic and political factors are relevant to understand the conditions behind very low levels of welfare state development.
\end{abstract}

Keywords: comparative social policy, QCA, social spending, social protection, welfare regimes 


\section{Introduction}

Why have some countries in Latin America and the Caribbean developed more extensive welfare systems than others? Do political and economic factors help us signal the (un)favourable paths taken by countries with different degrees of welfare state development in the XXI century? The primary purpose of this paper is to address these two questions to continue (re)searching the causal conditions and common/divergent paths of welfare state development in the region.

Recent comparative studies have highlighted several variables and theories that could help us understand the different levels of welfare state development in the region, as well as the factors behind the emergence, consolidation and expansion of the welfare systems. The policy legacies of welfare institutions matter, as there is a strong positive relationship between the historical experience of social security systems and the development of the welfare state in the region (Grassi, 2014; Mesa-Lago, 1978; Sanchez de Dios, 2015). Democracy has been considered a necessary although not sufficient condition for welfare state development Cruz-Martinez, 2017a; Graziano \& Jessoula, 2018). Closely linked to the previous argument, research has shown how democracy enabled the 'left' to implement redistributive policies after the Washington Consensus (Huber \& Stephens, 2012) and facilitated the inclusion of 'outsiders' into the social protection systems (Garay, 2016; Zarate Tenorio, 2014). Social and labour mobilisation combined with "the electoral competition for the vote of outsiders" and low-income voters are the main drivers behind the social policy expansion in the inclusive 21st century (Fairfield \& Garay, 2017; Garay, 2016, p. 25).

Politics matters, as shown by the previous paragraph. However, the literature has also confirmed that economics matters to explain welfare state development in Latin America. Low levels of economic development and democratisation appear to be the main reasons behind the relatively low levels of welfare state development in eight Latin American countries (Cruz-Martinez, 2017a). Martín-Mayoral and Sastre (2017) argues that the fiscal burden and external debt are the main drivers of welfare effort - measured as social spending - in the Washington Consensus years (1990-2000), while in addition to the fiscal burden, economic openness and GDP per capita are the main determinants during the pink-tide era (2001-2012).

However, one of the main limitations of welfare states scholarship in Latin America and the Caribbean is the simple conceptualisation of the Welfare State as an entity provider of cash transfers. As a consequence, researchers most commonly operationalise the Welfare State variable by its social spending dimension referring to the welfare effort concept (e.g., social spending as a percentage of GDP, social spending per capita) (Haggard \& Kaufman, 2009; Segura-Ubiergo, 2007). Recent research has demonstrated that it is possible to operationalise the welfare state by its multidimensional reality, taking into account the following dimensions: social spending, coverage of welfare programs and outcomes of welfare institutions (CruzMartinez, 2017b). Nevertheless, further research is needed to confirm the (combination of) factors behind the welfare expansion in the globalisation era, where social assistance programs (e.g., CCTs, social pensions) became the flagship anti-poverty programs in the social policy menu of governments in and outside the pink-tide, creating in the region what Barrientos (2019) calls dual and fragmented social protection institutions. Also, research must include additional dimensions of the welfare state when operationalizing the dependent variable by its multidimensional reality (e.g. quality of the coverage).

This paper addresses some limitations of previous comparative research in the region. First, welfare state development is conceptualised and operationalised by its multidimensional reality. A composite multidimensional welfare state development index is constructed for 18 countries in the region for the period 2000-2015. The four dimensions considered are social expenditure, the scope of coverage of welfare programmes, quality of the coverage of welfare programmes and outcomes of welfare institutions. Second, the papers combine a multiplicity of indicators to test the possibility of identifying a common path of economic and political sufficient conditions followed by countries with similar degrees of welfare state development. The causal conditions considered are openness to external shocks, debt obligations, revenuecollection capabilities, the power of the labour movement, strength of the left, policy legacies of welfare institutions, size of the outsider population and quality of democracy.

Crisp-set qualitative comparative analysis (csQCA) is the technique used to test the paths of causal conditions for the following outcomes: comparatively high-medium, low and very low welfare state development. The period considered in the operationalisation of the outcomes (i.e., degrees of welfare state development) is 2000-2015. Meanwhile, political and economic factors used as causal conditions refer to the period 1990-2015. Ten years from the Washington Consensus era (1990-2000), are included in the causal conditions because the economic and political processes and reforms in this period might add relevant information to understand welfare state development in the $21^{\text {st }}$ century. This decision highlights the importance of path-dependency, and how processes and reforms in a direction induce a continuation in the same path due to the dynamics of 'increasing returns' (Pierson, 2000). 
The paper confirms that both comparatively high-revenue capabilities and high degree of democratic strength are necessary conditions for a medium-high welfare state development, and its combined presence is a sufficient condition for having one of the top six welfare state development. On the other hand, the absence of a comparatively high democratic strength, high revenue capabilities, high historical experience of social protection programmes, and high labour movement strength are necessary conditions for a very low level of welfare state development. The combined absence of these four conditions is a sufficient condition for this outcome.

\section{Research Design}

First, the paper defines the outcomes of interest and the methodology used to operationalise the welfare state development by its multidimensional reality. Second, the article outlines the causal conditions and their expected relationship with the welfare state development according to the literature. Third, the crispset qualitative comparative analysis is conducted to confirm if countries with similar degrees of welfare state development in the $21^{\text {st }}$ century followed a similar path of economic and political factors in the postneoliberal era [i.e., a combination of (un)favourable causal conditions]. Later, the paper presents the results of the analysis and answer the research questions. The article ends with a general conclusion.

\subsection{Outcome being examined: the degree of welfare state development}

The concept of welfare state development refers to the progress of social protection programs, services and institutions that address social risks of the population (Cruz-Martinez, 2014). This concept captures (i) the magnitude of social investment, (ii) the scope and quality of coverage of welfare programmes and (iii) the outcomes of welfare institutions. Therefore, it provides information on the degree or magnitude of development of the welfare systems, but it does not distinguish the various means used by countries to achieve that development (e.g. the 'how'). Those interested in the important 'how' matter should refer to the abundant welfare regimes literature, which allows depicting the interdependent way welfare providers combine to allocate social risks and produce well-being. ${ }^{1}$

Previous research operationalised welfare state development by its multidimensional reality using principal component analysis to reflect the level of development among the Latin American emerging welfare states during the consolidation period and the 2000-2010 period (Cruz-Martinez, 2017b). However, the main limitation is that welfare state development results were relative to the sample of 18 Latin American countries used. The inclusion of another country in the region - or from outside the region - would alter the results of every country. This paper follows a different methodology in order to be able to solve this "relativity problem". Moreover, a broader set of indicators (i.e., fifteen versus eight) and a fourth dimension (i.e. the quality of coverage) are incorporated in the construction of the Welfare State Development Index (WeSDI).

The WeSDI is a composite summary measure of progress in four key dimensions of welfare state development: the magnitude of social investment, the scope of coverage of welfare programmes, the outcomes of welfare institutions, and the quality of the coverage. Following the Human Development Index methodology (UNDP, 2018), the WeSDI is the geometric mean of normalised indices for each of the four dimensions previously mentioned.

Table 1 shows the data used to construct each of the four indices. Data comes from reputable databases, from international organisations, or from scholars' databases, which provide comparable cross-sectional data. We aim to include data on health, education, social assistance and social insurance programs in each of the four dimensions. The fitness of each indicator for each dimension follows an analytical criteria rather than statistical fitness.

There are two steps to calculating the WeSDI: (i) creating the four dimension indices, and (ii) aggregating the dimensional indices to produce the Welfare State Development Index (WeSDI). First, to create the four dimension indices, initial data is standardised with values between 1 and 0 using goalposts (i.e. natural zeros and aspirational targets). The last two columns of Table 1 show the set values for the goalposts.

\footnotetext{
${ }^{1}$ See Barrientos (2004) for a common regional welfare regime for Latin America. See Barba Solano (2005); Filgueira (1999); Marcel and Rivera (2008); Martínez Franzoni (2008); Pribble (2011) for intra-regional welfare regimes in the region. See Cruz-Martinez (2018) for intra-national welfare regimes in the region.
} 
Table 1: Indicators of welfare state development (2000-2015)

\begin{tabular}{|c|c|c|c|c|c|}
\hline \multirow{2}{*}{$\begin{array}{l}\text { Dimensions and } \\
\text { number of indicators }\end{array}$} & \multirow[b]{2}{*}{ Description of indicators } & \multirow{2}{*}{ Years } & \multirow{2}{*}{ Source } & \multicolumn{2}{|c|}{ Goalposts } \\
\hline & & & & Min & Max \\
\hline \multirow{3}{*}{$\begin{array}{l}\text { Magnitude of social } \\
\text { investment (three } \\
\text { indicators) }\end{array}$} & $\begin{array}{l}\text { Social spending per capita (constant prices in US } \\
\text { dollars of 2010) }\end{array}$ & $\begin{array}{l}\text { Average } \\
2000-2015\end{array}$ & CEPAL (2018a) & 0 & 11398 \\
\hline & Social spending ( $\%$ of Gross Domestic Product) & $\begin{array}{l}\text { Average } \\
2000-2015\end{array}$ & CEPAL (2018a) & 0 & 18.6 \\
\hline & Social spending ( $\%$ of total expenditure) & $\begin{array}{l}\text { Average } \\
2000-2017\end{array}$ & CEPAL (2018a) & 0 & 54.1 \\
\hline \multirow{6}{*}{$\begin{array}{l}\text { Scope of coverage of } \\
\text { welfare programmes ( } \mathrm{six} \\
\text { indicators) }\end{array}$} & $\begin{array}{l}\text { Share of salaried workers with the right to pensions } \\
\text { when retired (affiliated to social security system) }\end{array}$ & $\begin{array}{l}\text { Average } \\
2000-2015\end{array}$ & $\begin{array}{l}\text { SEDLAC (CEDLAS } \\
\text { and The World Bank) } \\
\qquad(2018)\end{array}$ & 0 & 100 \\
\hline & $\begin{array}{l}\text { Share of people aged } 65 \text { or older who receive a } \\
\text { social insurance retirement pension }\end{array}$ & $\begin{array}{l}\text { Average } \\
2000-2015\end{array}$ & $\begin{array}{c}\text { Inter-American } \\
\text { Development Bank } \\
\text { (2018) }\end{array}$ & 0 & 100 \\
\hline & $\begin{array}{l}\text { Share of unemployed receiving regular periodic } \\
\text { social security unemployment benefits }\end{array}$ & $\begin{array}{l}\text { Average } \\
2000-2015\end{array}$ & ILO (2018) & 0 & 100 \\
\hline & $\begin{array}{l}\text { Social pensions coverage for those above the age } \\
\text { eligibility }\end{array}$ & $\begin{array}{l}\text { Around } \\
2013\end{array}$ & $\begin{array}{l}\text { Inter-American } \\
\text { Development Bank } \\
\text { (2018) }\end{array}$ & 0 & 100 \\
\hline & CCT coverage as a $\%$ of income-poor population & $\begin{array}{l}\text { Around } \\
2013\end{array}$ & $\begin{array}{l}\text { Inter-American } \\
\text { Development Bank } \\
\text { (2018) }\end{array}$ & 0 & 100 \\
\hline & $\begin{array}{l}\text { Share of the population participating in Social } \\
\text { Protection and Labor programs (includes direct and } \\
\text { indirect beneficiaries) in the poorest quintile }\end{array}$ & $\begin{array}{l}\text { Average } \\
2005-2015\end{array}$ & World Bank (2018a) & 0 & 100 \\
\hline \multirow{3}{*}{$\begin{array}{l}\text { Outcomes of welfare } \\
\text { institutions (three } \\
\text { indicators) }\end{array}$} & $\begin{array}{l}\text { Infant mortality rate, under five years of age (per } \\
100 \text { live births) }\end{array}$ & $\begin{array}{l}\text { Average } \\
2000-2015\end{array}$ & World Bank (2018b) & 100 & 0 \\
\hline & $\begin{array}{l}\text { Percentage of pupils starting grade } 1 \text { who reach last } \\
\text { grade of primary }\end{array}$ & $\begin{array}{l}\text { Average } \\
2000-2015\end{array}$ & CEPAL (2018a) & 0 & 100 \\
\hline & $\begin{array}{l}\text { Poverty Headcount reduction due to Social } \\
\text { Protection and Labor programs (\% of the } \\
\text { population) }\end{array}$ & $\begin{array}{l}\text { Average } \\
2005-2015\end{array}$ & World Bank (2018a) & 0 & 60,8 \\
\hline \multirow{3}{*}{$\begin{array}{l}\text { Quality of the coverage } \\
\text { (three indicators) }\end{array}$} & $\begin{array}{l}\text { Gender gap in the average pension transfer (non- } \\
\text { contributory }+ \text { contributory for }+65 y \text { ) }\end{array}$ & $\begin{array}{l}\text { Around } \\
2015\end{array}$ & CEPAL (2018b) & 100 & 0 \\
\hline & $\begin{array}{l}\text { Average number of pupils per teacher (primary and } \\
\text { secondary) }\end{array}$ & $\begin{array}{c}\text { Average } \\
2000-2015\end{array}$ & CEPAL (2018a) & 50,4 & 13 \\
\hline & $\begin{array}{l}\text { Out-of-pocket health expenditure (\% of total health } \\
\text { expenditure) }\end{array}$ & $\begin{array}{l}\text { Around } \\
2014\end{array}$ & PAHO/WHO (2017) & 100 & 0 \\
\hline
\end{tabular}

Note: Social protection refers to the central government social expenditure in the areas of housing, education, health and social protection (COFOG)

The natural zero in every indicator of the magnitude of the social investment dimension is based on the logic that states can be completely absent in the welfare-mix of societies (i.e. representing the ideal of orthodox liberalism). The aspirational target is the average score of four Nordic countries with universal welfare regimes (Norway, Denmark, Sweden and Iceland). Following a similar logic from the first dimension, all six indicators in the scope of coverage dimension show the minimum potential value of coverage in social protection programmes. The maximum value in the indicators of the second dimension, 100 , is justified by the aspirational target of universal coverage in contributory pensions, unemployment programmes, social pensions, and conditional cash transfer programmes.

One hundred is the natural zero of three indicators in the third and fourth dimension. One hundred is the less desired outcome in each of the three indicators, where infant mortality under five years will be one hundred per cent, the gender gap in the average transfer pension will be absolute, and the total health expenditure will equal the out-of-pocket health expenditure. On the contrary, the aspirational target in these indicators, 0 , showcase a welfare system without infant mortality, with gender equality in cash transfers for the older-age, and with universal health care with an absolute benefit level.

In a failed education system, the share of pupils starting grade 1 who reach last grade of primary school would be zero. On the contrary, a successful education system would have a perfect completion rate in primary education. A failed social protection and labour program would not reduce the poverty headcount ratio, justifying the minimum value of zero. The aspirational value for the poverty headcount ratio indicator uses the average of the most successful programs in the ASPIRE database: Hungary, Romania, Ukraine, Poland and Serbia. The remaining indicator from the quality of coverage dimension, average number of pupils per teacher, have as a natural zero the average number of pupils in the two countries with the lowest PISA scores (i.e., Malawi and Mozambique) and as aspirational targets the number of pupils in the five highest PISA scores (i.e., Singapore, Hong Kong, Japan, Macau and Estonia). 
Having defined the natural zeros (minimum values) and aspirational targets (maximum values), the dimension indices are calculated as:

$$
\text { Dimension index }=\frac{\text { actual value }- \text { minimum value }}{\text { maximum value }- \text { minimum value }}
$$

Equation 1 is first applied to each of the 15 indicators, and then the arithmetic means of the three resulting indices in the first dimension, the six indices in the second dimension, the three indices in the third dimension and the three indices in the fourth dimension are taken to construct the WeSDI. The arithmetic means arbitrarily assign the same weight to each of the original indicators in the dimension indices. Because data is standardised, indicators can be put together in a composite index, even though they initially had different ranges of value.

The second step involves the aggregation of dimensional indices to produce the WeSDI. The WeSDI is the geometric mean of the four-dimensional indices:

$$
W e S D I=\left(I_{\text {Social investment }} \cdot I_{\text {coverage }} \cdot I_{\text {outcomes }} \cdot I_{\text {quality of coverage }}\right)^{1 / 4}
$$

Table 2 shows the results of the dimensional indices and the WeSDI. Countries were grouped using fixed cutoff points, resulting in four categories of welfare state development achievements. The cutoff points values in the HDI are calculated "using the quartiles from the distributions of the component indicators" (UNDP, 2018, p. 3). However, we are not able to conduct the same analysis here because we only have the results for Latin American countries, and not for the majority of countries in the world. Further research should expand this database to have WeSDI indicators of all countries with available data, and be able to use quartiles from the distributions of the component indicators of all countries as cut-off points.

Table 2: Standardised dimensional indices and the results of the WeSDI

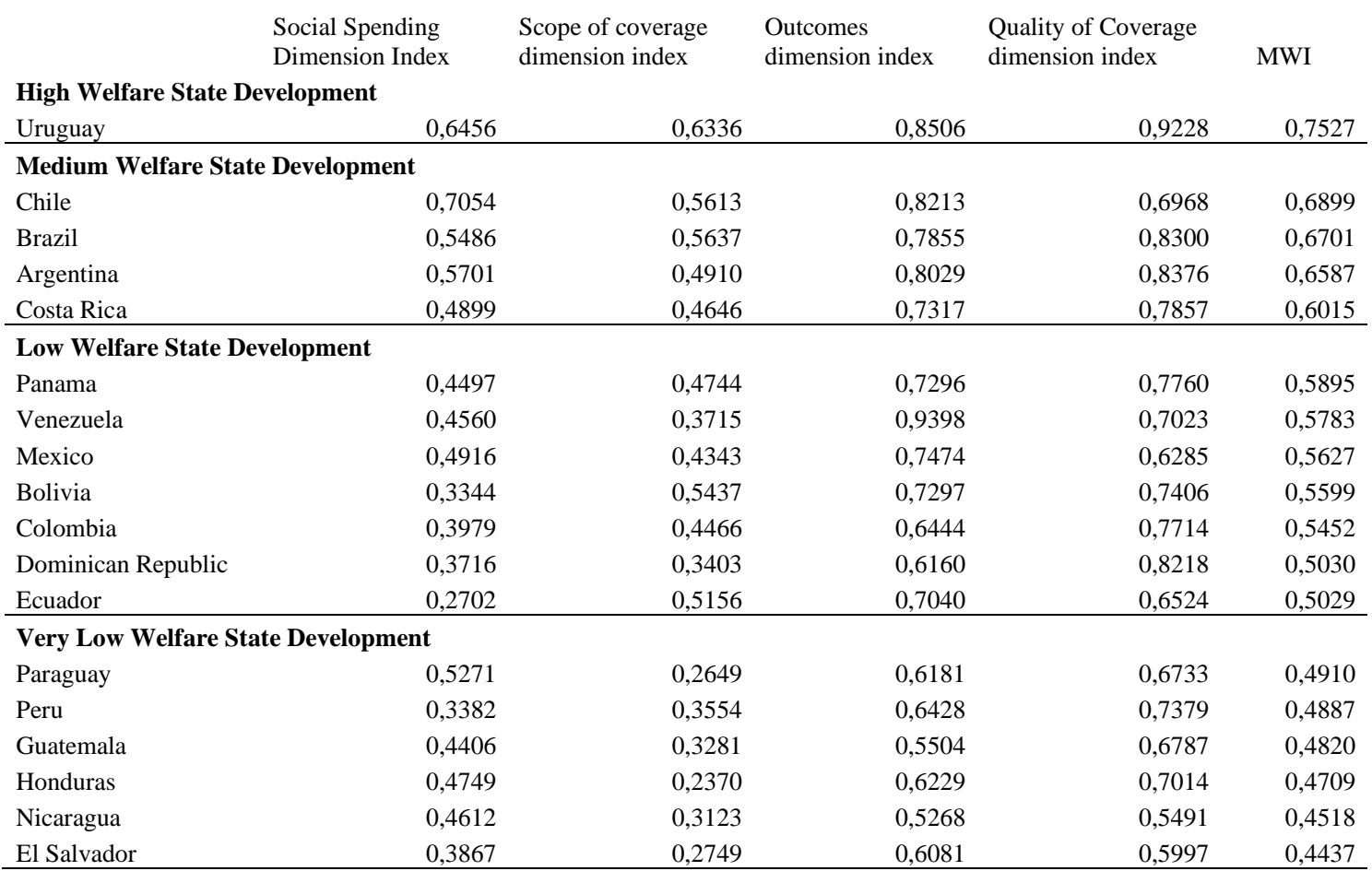


Therefore, the WeSDI uses a modified version of the HDI cutoff points. Countries with a score above 0,800 are categorised as countries with very high welfare state development. Those with a score between 0,700 and 0,799 are in the high welfare state development category. Countries with a score between 0.600 and 0.699 are categorised as medium welfare state development, and those with a score between 0,500 and 0,599 are in the low welfare state development. Finally, countries with a score below 0,499 are categorised under the very low welfare state development group.

\subsection{Theoretical framework on political and economic causal conditions}

This section describes three economic and five political causal conditions for welfare state development available in the literature. A theoretical overview of the relationship between the causal conditions and the welfare state development is briefly pointed out. Finally, the section describes the operationalisation of indicators and the criteria for their incorporation in the csQCA.

\subsubsection{Economic factors}

There are two opposing views in the literature about the impact of economic openness and globalisation on welfare state development. One on one side, the 'efficiency hypothesis' or 'race to the bottom' argues that there is a negative relationship among variables. Openness and globalisation lead governments to cut social expenditure and state-provided welfare because of internal and external pressures for competitiveness and foreign direct investment attraction (Kurtz \& Brooks, 2008; Rudra, 2002). Tanzi (2002) argues that globalisation affects the government's ability to provide social protection. On the other hand, the 'compensation hypothesis' argues the existence of a positive relationship among variables. Openness and globalisation expose countries to external shocks making individuals more vulnerable to labour and economic insecurity; therefore, individuals are expected to demand more social investment from the state to face social risks due to these external shocks (Kaufman \& Segura-Ubiergo, 2001; Rodrik, 1998; SeguraUbiergo, 2007).

The composite index 'openness to external shocks' is used to operationalise economic openness and globalisation. The index is the arithmetic mean of the following two normalised indicators ( $\max 1, \min 0$ ): the degree of openness of the economy and the KOF globalisation index. "The Degree of Openness of the Economy measures the magnitude of external trade with respect to the country's domestic production" (CEPAL, 2018a) (i.e. it is the ratio between the sum of the exports and the imports to the total GDP). The KOF globalisation index is a tridimensional indicator capturing the economic, political and social globalisation. Following Keohane Keohane and Nye (2000, p. 4), Dreher (2006, p. 1092) argues that

"economic globalization, [is] characterized as long-distance flows of goods, capital and services as well as information and perceptions that accompany market exchanges; political globalization, [is] characterized by a diffusion of government policies; and social globalization, [is] expressed as the spread of ideas, information, images and people."

Data for both indicators refer to the average in the post-neoliberal era (1990-2015) and comes from the CEPALSTAT and Gygli, Haelg, and Sturm (2018), respectively. In the QCA, countries with openness to external shocks above the sample mean are considered as countries with a relatively high openness, while countries with openness to external shocks below the sample mean are considered as countries with relatively low openness. Table 3 shows the results for this and the rest of the causal conditions.

The literature also highlights both public indebtedness and revenue-collection capabilities as economic factors shaping the welfare effort. High-interest payments and disproportionate debt ratios reduce social expenditure in the areas of social protection, health and education (Dion, 2006; Lora, 2009; Lora \& Olivera, 2007). Lower revenues translate into more significant constraints of social welfare provision. Haggard and Kaufman (2004) argued that the fragility of tax-collecting institutions in Latin America is one of the reasons to explain the low levels of welfare effort during the 1980s-1990s. Higher levels of government's revenue collection are essential to promote economic development in Latin America, as additional tax revenues enable governments to increase social spending, infrastructure and innovation (OECD, IADB, \& ECLAC, 2014). Following the 'logic of industrialism' and 'Wagner's law', Wilensky (1975) confirmed that economic growth is one of the leading causes of the emergence of the welfare states, while Lamartina and Zaghini (2011) confirmed the positive relationship between public spending and gross domestic product growth. Researchers have also found a positive relationship between tax revenue and GDP per capita (Tanzi $\&$ Zee, 2000). Consequently, higher revenue collection capabilities (i.e., higher fiscal burdens) alongside higher economic growth and GDP per capita is expected to increase the feasibility to finance and provide social welfare programmes. 
Table 3: Normalised scores for economic and political factors in the post-neoliberal era

\begin{tabular}{|c|c|c|c|c|c|c|c|c|}
\hline & \multicolumn{3}{|c|}{ Economic factors } & \multicolumn{5}{|c|}{ Political factors } \\
\hline & $\begin{array}{c}\text { Openness } \\
\text { to external } \\
\text { shocks }\end{array}$ & Debt & $\begin{array}{c}\text { Revenue } \\
\text { capabilities }\end{array}$ & $\begin{array}{c}\text { Labour } \\
\text { movement's } \\
\text { power }\end{array}$ & $\begin{array}{l}\text { Strength } \\
\text { of the left }\end{array}$ & $\begin{array}{c}\text { Policy legacy } \\
\text { of welfare } \\
\text { institutions }\end{array}$ & Outsiders & Democracy \\
\hline Argentina & 0,401 & 0,318 & 0,645 & 0,498 & 0,308 & 0,691 & 0,652 & 0,673 \\
\hline Bolivia & 0,283 & 0,255 & 0,353 & 0,302 & 0,522 & 0,338 & 0,335 & 0,440 \\
\hline Brazil & 0,094 & 0,451 & 0,527 & 0,693 & 0,392 & 0,644 & 0,466 & 0,784 \\
\hline Chile & 0,665 & 0,129 & 0,735 & 0,141 & 0,234 & 0,813 & 0,000 & 0,756 \\
\hline Colombia & 0,051 & 0,448 & 0,386 & 0,086 & 0,000 & 0,403 & 0,455 & 0,145 \\
\hline Costa Rica & 0,592 & 0,575 & 0,548 & 0,083 & 0,619 & 0,319 & 0,264 & 0,973 \\
\hline $\begin{array}{l}\text { Dominican } \\
\text { Republic }\end{array}$ & 0,221 & 0,119 & 0,407 & 0,076 & 0,503 & 0,175 & 0,798 & 0,152 \\
\hline Ecuador & 0,269 & 0,423 & 0,240 & 0,504 & 0,545 & 0,381 & 0,313 & 0,332 \\
\hline El Salvador & 0,355 & 0,393 & 0,144 & 0,075 & 0,295 & 0,084 & 0,495 & 0,000 \\
\hline Guatemala & 0,197 & 0,204 & 0,164 & 0,026 & 0,192 & 0,000 & 0,384 & 0,016 \\
\hline Honduras & 0,524 & 0,394 & 0,204 & 0,055 & 0,108 & 0,003 & 0,485 & 0,001 \\
\hline Mexico & 0,348 & 0,261 & 0,428 & 0,092 & 0,088 & 0,253 & 0,162 & 0,199 \\
\hline Nicaragua & 0,245 & 0,667 & 0,190 & 0,047 & 0,472 & 0,219 & 0,403 & 0,157 \\
\hline Panama & 0,840 & 0,504 & 0,679 & 0,045 & 0,476 & 0,244 & 0,329 & 0,511 \\
\hline Paraguay & 0,279 & 0,000 & 0,192 & 0,047 & 0,065 & 0,172 & 0,564 & 0,068 \\
\hline Peru & 0,302 & 0,415 & 0,374 & 0,050 & 0,250 & 0,347 & 0,287 & 0,231 \\
\hline Uruguay & 0,601 & 0,308 & 0,621 & 0,409 & 0,497 & 1,000 & 0,145 & 1,000 \\
\hline Venezuela & 0,298 & 0,326 & 0,364 & 0,017 & 1,000 & 0,441 & 1,000 & 0,196 \\
\hline Average & 0,365 & 0,344 & 0,400 & 0,180 & 0,365 & 0,363 & 0,419 & 0,368 \\
\hline SD & 0,205 & 0,167 & 0,190 & 0,206 & 0,245 & 0,273 & 0,237 & 0,335 \\
\hline
\end{tabular}

Nonetheless, Garay (2016, p. 12) argues that economic resources does not explain why governments in the 1990s and after were willing to expand social policy to outsiders, while Graziano and Jessoula (2018, p. 15) adds that "the logic of industrialism approach is neither able - alone - to explain the emergence of different welfare regimes not to give account of the diverse welfare efforts in countries with similar level of economic development". Therefore, economics appears to matter but not enough to be the sole driving factor behind the welfare state emergence, consolidation or expansion.

The composite index 'debt obligations' will measure the potential fiscal constraints by external debt. This index is the arithmetic mean of the following two normalised indicators $(\max 1, \min 0)$ : total external debt as a percentage of GDP and the ratio of interest payments to central government's current revenue. Data for both indicators refer to the average in the post-neoliberal era (1990-2015) and comes from the CEPALSTAT. In the QCA, countries with debt obligations above the sample mean are considered as countries with a relatively high level of indebtedness, while countries with debt obligations below the sample mean are considered as countries with a relatively low level of indebtedness.

The composite index 'revenue-collection capabilities' is the arithmetic mean of the following three normalised indicators ( $\max 1$, min 0): equivalent fiscal burden as a percentage of GDP, expenditure-side real GDP per capita at chained PPPs (in 2011US\$), and the rate of growth of total annual GDP at constant prices. The equivalent fiscal burden is the sum of tax revenues - including social contributions to the health and pension systems - mandatory private actuarial contributions and the income derived from natural resources (Barreix, Corrales, Díaz, \& Garcimartín, 2017). Data for the first and third indicators refer to the average in 1990-2015, while the series of the second indicator ends in 2014. Fiscal burden data comes from the Latin America and the Caribbean Fiscal Burden Database (IADB \& CIAT, 2017), GDP per capita data comes from the Penn World Table 9 (Feenstra, Inklaar, \& Timmer, 2015), and economic growth data comes from CEPALSTAT. In the QCA, countries with revenue-collection capabilities above the sample mean are considered as countries with a relatively high level of revenue capabilities, while countries with debt obligations below the sample mean are considered as countries with relatively low revenue capabilities.

\subsubsection{Political factors}

The strength of the labour movement and the 'left' in government has been signalled as one of the main explanatory factors in consolidated welfare states (Esping-Andersen, 1990). The power resources theory argue that the strength of leftist parties and the level of mobilisation of the left are the main determinants of the size and distributional impact of the welfare state (Korpi, 1983). Niedzwiecki (2015) confirmed in a cross-country analysis that trade union strength has a statistically significant and positive effect on social expenditure in South America. The ratio of workers affiliated to labour unions increases the bargaining power of the labour movement and gives unions a more exceptional ability to disrupt the economy, lobby for social welfare reforms and more freedom from the free-rider (Sullivan, 2010; Wallerstein, 1989). 
Roberts (2002) downplays the explanatory powers of the left-labour strength in the Latin American region, especially compared to Europe. Ewig (2016) confirms that the insignificance of the left behind the convergence towards an equity social policy in the region after the Washington Consensus era, while democracy and especially electoral competition were crucial explanatory factors. However, Pribble and Huber (2013) highlight the role played by left-wing governments in the welfare state reforms with a socialdemocratic character of Chile and Uruguay. Research has shown that right-wing parties are less likely to pursue policies that promote the welfare state (Amable, Gatti, \& Schumacher, 2006) and favour more modest welfare benefits than left or centre-left governments (Pribble, 2013). However, Niedzwiecki and Pribble (2017) recently showed that right-wing governments in Argentina and Chile have not engaged in deep social spending cuts. It seems that:

"policy legacies and the strength of the opposition help to explain these outcomes, suggesting that Latin America's political context has been transformed by the consolidation of democracy and the experience of left party rule" (Niedzwiecki \& Pribble, 2017, p. 72).

Trade union density rates and the collective bargaining coverage rate measure the labour unions' institutionalised power resources. A composite index of institutionalised power resources is built with the arithmetic mean of both normalised indicators $(\max 1, \min 0)$. The number of strikes and lockouts, days not worked due to strikes and lockouts, and the workers involved in strikes and lockouts are the three indicators measuring the labour unions' non-institutionalised power resources. A composite index of noninstitutionalised power resources is built with the arithmetic mean of the previously mentioned three normalised indicators $(\max 1, \min 0)$. Finally, the variable 'labour movement's power' is operationalised as the arithmetic means of the institutionalised and non-institutionalised power resources indices. Data for all five indicators refer to the average between 2000-2015 and comes from the ILOSTAT (ILO, 2018). The trade union density rates for Ecuador and Honduras come from SEDLAC (CEDLAS and The World Bank) (2018) because data was not available in ILOSTAT. In the QCA, countries with labour movement's power above the sample mean are considered as countries with a relatively high level of labour strength, while countries with labour movement's power below the sample mean are considered as countries with a relatively low level of labour strength.

The strength of the left is a composite index constructed with an arithmetic mean of the following two normalised indicators ( $\max 1, \min 0$ ): (i) the seat share of centre-left and left parties in the lower house ${ }^{2}$, and (ii) strength of left governments. The first indicator, seat share, refers to the average proportion of seats received by centre-left and left parties in lower house legislative sessions during periods of democratic rule from 1990-2012. The strength of the left government is a composite index obtained by multiplying (i) the share of years of centre-left and left governments in each country between 1990-2012 by (ii) the seat share of centre-left and left legislators in the lower house from the party of the executive. The combination of these two indicators in the strength of left government composite index aims to capture not only the number of years the left was in the head of the government but also how strong was its presence in the lower house, which would facilitate reforms for redistribution and welfare state development. Data comes from Huber and Stephens (2016) Latin America and Caribbean Political Dataset. In the QCA, countries with a strength of the left above the sample mean are considered as countries with relatively high strength of the left, while countries with a strength of the left below the sample mean are considered as countries with relatively low strength of the left.

Democracy matters and it has played a crucial role in the development of the welfare state during the consolidation and social policy expansion era. Huber and Stephens (2012) highlight the crucial role of democratic regimes in the 1980-2005 period. Democracy is a catalyst "at the beginning of the causal chain" that makes possible the political organization and mobilization of the left, which in the long run was a key ingredient for the implementation of redistributive policies in the region and the respective policy outcomes of poverty and inequality reductions (Huber \& Stephens, 2012, p. 7). Haggard and Kaufman (2004) emphasise the role played by electoral and interest group competition in a democratic regime in the consolidation period (ISI era) and the 'inclusive turn'. A comparative study including seventeen countries of the region concluded that the combined absence of a lasting democracy and a high economic/industrial development in the state-led industrialization era (consolidation phase) is the main reason behind the relatively low level of welfare state development in Colombia, Ecuador, Peru, Dominican Republic, El Salvador, Bolivia, Guatemala and Paraguay (Cruz-Martinez, 2017a).

\footnotetext{
${ }^{2}$ For the case of Argentina, the alternatives measures proposed by Huber and Stephens were adopted. Rather than considering the Kirchners executive governments as 'other' -like Coppedge (1997) does - the Kirchners' governments are considered Secular centre-left. El seat share in the lower house is also modified to show the Peronist parties aligned with the Kirchners.
} 
Regarding the inclusive turn, Garay (2016, p. 16) confirms democracy is a precondition for social policy expansion and distinguishes "two politically driven processes: one 'from above' motivated by electoral competition for outsiders voters (..) and one 'from below' propelled by social mobilisation". Closely linked to the left strength variable, Garay finds that when conservative and centre-right parties are strong and the expansion is negotiated among political parties in congress, resultant social policies tend to be restrictive (i.e., the inclusion of a small number of outsiders and with low benefit levels). However, when social movements are involved in the negotiation of the social policy expansion, it tends to produce an inclusive expansion (i.e., the inclusion of a large number or all outsiders with a relatively generous benefit level).

Most countries in the region have had democratic regimes during a large part of 1990-2015. Therefore, it is not useful to operationalise democracy with binary codes to show the presence or absence of democracy. The same applies to the number of years of democratic experience, in contrast to semi-democracy and autocracy (see Mainwaring, Brick, \& Perez-Liñan, 2001). Therefore, democracy is operationalised using the multidimensional varieties of democracy dataset (Coppedge, Gerring, Knutsen, Lindberg, Skaaning, et al., 2018; Pemstein et al., 2018). Democracy is then the geometrical mean of the following five "macrolevel indices that describe features of democracy at the highest (most abstract) level": electoral democracy ${ }^{3}$ liberal democracy ${ }^{4}$, deliberative democracy ${ }^{5}$, participatory democracy ${ }^{6}$, and egalitarian democracy ${ }^{7}$ (Coppedge, Gerring, Knutsen, Lindberg, ing, et al., 2018, p. 40). Before creating the composite index of democracy, the five indicators were normalised $(\max 1, \min 0)$. Data for all five indicators refer to the average between 1990-2015. In the QCA, countries with a democracy score above the sample mean are considered as countries with a relatively high level of democratic strength, while countries with a democracy score below the sample mean are considered as countries with a relatively low level of democratic strength.

The size of the outsider population refers to the percentage of the population not participating in social protection and labour programs (includes direct and indirect beneficiaries). Data refer to the average between 2005-2015 and comes from national household surveys - except Argentina, which is an urban survey - in the ASPIRE database (World Bank, 2018a). In the QCA, countries with the size of outsiders above the sample mean are considered as countries with a relatively high proportion of outsiders, while countries with a size of outsiders below the sample mean are considered as countries with a relatively low proportion of outsiders. Taking into consideration that all countries in the study are liberal democracies although with variant degrees in terms of quality of their democracies - one could argue that a higher share of outsider population would increase the electoral competition for these votes. The higher the population who benefited from the social policy expansion in the post-neoliberal era, could translate to higher electoral competition for outsider voters - what Garay calls the "politically driven process from above".

The pioneering research by Mesa-Lago $(1978,1983)$ states the potential relevance of considering the policy legacies of welfare institutions to understand the degree of welfare state development in the post-neoliberal era. Mesa-Lago (1994) classified Latin American countries based on the date in which the first social protection programme was created. He categorizes countries in three groups - pioneers (Argentina, Brazil, Chile, Cuba and Uruguay), intermediates ( Bolivia, Colombia, Costa Rica, Ecuador, Mexico, Panama, Paraguay, Peru and Venezuela), and latecomers (Dominican Republic, El Salvador, Guatemala, Haiti, Honduras, Nicaragua) - paying particular attention to the importance of the historical experience for the correct functioning of welfare institutions. Pioneers created the first welfare programme in the 1920s-1930s, the intermediate group in the 1940s-1950s, and the latecomers after the 1950s. While studying the causal conditions of welfare state development in the consolidation era, previous research confirmed that pioneer

\footnotetext{
3 "The electoral principle of democracy seeks to embody the core value of making rulers responsive to citizens, achieved through electoral competition for the electorate's approval under circumstances when suffrage is extensive; political and civil society organizations can operate freely; elections are clean and not marred by fraud or systematic irregularities; and elections affect the composition of the chief executive of the country" (Coppedge, Gerring, Knutsen, Lindberg, ing, et al., 2018, p. 40).

4 "The liberal principle of democracy emphasizes the importance of protecting individual and minority rights against the tyranny of the state and the tyranny of the majority" (Coppedge, Gerring, Knutsen, Lindberg, ing, et al., 2018, p. 40).

5 "The deliberative principle of democracy focuses on the process by which decisions are reached in a polity" (Coppedge, Gerring, Knutsen, Lindberg, ing, et al., 2018, p. 41).

6 "The participatory principle of democracy emphasizes active participation by citizens in all political processes, electoral and non-electoral" (Coppedge, Gerring, Knutsen, Lindberg, ing, et al., 2018, p. 41).

7 "The egalitarian principle of democracy holds that material and immaterial inequalities inhibit the exercise of formal rights and liberties, and diminish the ability of citizens from all social groups to participate" (Coppedge, Gerring, Knutsen, Lindberg, ing, et al., 2018, p. 42).
} 
countries exhibited the highest degree of social expenditure, coverage and outcomes of welfare institutions (Cruz-Martinez, 2017a). History matters, therefore, the historical experience of welfare institutions and programmes in a country - with strongest or weakest retrenchment and privatisations - might offer a significant causal condition of the functioning, institutionalisation, and development of the welfare state in post-neoliberal Latin America.

The policy legacies of welfare institutions is operationalized as the average number of years since the creation of the first social protection law until 2015 in the following areas: (i) old age, disability, survivors, (ii) sickness, maternity, (iii) work injury, (iv) unemployment, and (v) family allowances. Following the path-dependency theory, the longest the historical experience of welfare programmes and institutions the strongest the incentives for countries to continue on the same path due to the dynamics of 'increasing returns'. Historical experience is calculated with data disaggregated by welfare program in the Social Security Programs Throughout the World publication (Social Security Administration, 2018). In the QCA, countries with a historical experience of welfare programmes above the sample mean are considered as countries with a relatively high level of welfare policy legacies of welfare institutions, while countries with historical experience below the sample mean are considered as countries with a relatively low level of welfare policy legacies.

\section{Methods}

Boolean algebra principles and crisp-set qualitative comparative analysis (csQCA) is used to track the path of eight political and economic causal conditions during 1990-2015 to help us understand why some countries in Latin America and the Caribbean have more developed welfare systems than others in the postneoliberal era. The purpose of this technique is to translate information from data into a truth-table where different combinations of conditions that produce a specific result can be identified. QCA is considered in the literature as a suitable alternative to quantitative regression-based approaches based on signalling significant explanatory variables and qualitative case-oriented approach, with the benefit of providing rigorous results with a small number of observations (Rihoux \& Ragin, 2009). [See Schneider \& Wagemann (2010) for details of good practices in QCA].

Ragin (1987) foresee this technique as a midpoint between qualitative (case-oriented) and quantitative (variable-oriented) approaches and rejects the argument that a single causality is determined in the QCA. In contrast, QCA allows determining a multiplicity of paths (combinations of causal conditions) that may lead to an outcome of interest (i.e., a specific degree of welfare state development as measured by the WeSDI). The researcher needs to determine how many membership sets are going to be considered in the examination of the outcome(s) of interest. The literature distinguishes three alternatives: crisp-set QCA (csQCA) for dichotomous relationships $(0,1)$, multi-value QCA (mvQCA) for multicotomic relationships $(0,0.5,1)$ and fuzzy-sets QCA (fsQCA) for fuzzy relationships (0-1) (Ragin, 2000, 2008; Ragin \& Davey, 2016).

The main distinction between the three types of QCA is the degree to which they satisfy membership criteria. In csQCA variables can only have two values. It distinguishes full-membership (1) versus nonmembership (0) (i.e. in vs out, high vs low). A second cut-off point is added in mvQCA, and variables have up to three values. Thirdly, in fsQCA, membership scores can vary from 0.0 to 1.0. This article relies on csQCA. With csQCA, the raw data of the cases in each of the conditions is dichotomized using empirical arguments. The sample mean of each of the political and economic conditions are used as cut-off points, to enable distinguishing, for example, between countries with a comparatively or relatively high and low degree of democratic strength, labour strength or debt obligations. When using the mean as a cut-off point we are following a relativistic rather than an absolutist approach. Following Rihoux \& De Meur (2009), "mechanical cut-off points such as the mean or median can be used, but one should check whether this makes sense considering the distribution of the cases" (Rihoux \& De Meur, 2009:42). We checked that the distribution of the cases and the dichotomisation made sense. ${ }^{8}$

After dichotomization and based on theoretical knowledge, the paper proceeds to test if there is a specific configuration of sufficient conditions (pathway) followed by countries with similar degrees of welfare state

\footnotetext{
${ }^{8}$ It would be a quite difficult task to be able to justify an objective or theoretically sound threshold, not only because of the nature of these conditions but also because most of them are composite indicators. How to justify that 30,40 , 50,60 , or 70 per cent is a reasonable cut-off point for economic openness? For example, Segura-Ubiergo (2007) used $30 \%$ as a threshold in his QCA analysis. However, I found this even more subjective than using "mechanical cut-off points". This is the reason for using the mean - and the 0.5 of the normalised index operationalising the causal conditions in the robustness check - as a cut-off point for obtaining relative results.
} 
development. ${ }^{9}$ A necessity analysis is used to identify necessary conditions and a truth-table is build to identify sufficient conditions.

Using qualitative binary matrices $(0,1)$, the absence or presence of favourable conditions between 19902015 is shown in a multiple truth-table. In csQCA, the calibration process requires dichotomizing the raw data of causal conditions values in two: a full-membership condition with a value of ' 1 ' and a no membership condition with a value of ' 0 '. A case exhibits a ' 1 ' if the condition exhibits a favourable feature for the desired outcome and a ' 0 ' if the case exhibits an unfavourable feature. Table 4 shows the multiple truth-table with the favourable (1) and unfavourable (0) conditions for welfare state development. Five possible outcomes of the WeSDI are mapped. Following Ragin (2008), sufficient conditions are highlighted at the end of the results section.

\section{Results}

The logic process of reducing the complex expression of raw data into binary matrices to determine the patters of causal conditions corresponding to the outcomes of interest may be performed either manually or using software such as fs/QCA, Tosmana, or the QCA package in R (Jordan et al. 2011). After analysing data in the multiple truth-table, we could identify common paths followed by countries with the six highest welfare state development scores (i.e., Uruguay, Argentina, Brazil, Chile, Costa Rica and Panama) and those with a very low level of welfare state development (El Salvador, Guatemala, Honduras, Nicaragua, Paraguay, Peru).

The multiple truth-table can be complicated to determine the configuration of conditions easily and visually in each of the examined outcomes. Table 5 shows the results of the different paths more simply, by signalling with a plus sign (+) the causal conditions where countries obtained a score above the sample mean-which might help track the commonalities among countries with similar degrees of welfare state development. The debt variable shows a plus sign in countries with a score below the sample mean. Shaded areas in Table 5 evidence the common (un)favourable conditions experienced by the top six countries in welfare state development and the six countries with a very low level of welfare state development.

The results can also be shown by translating the pathways in a descriptive formula. This formula is a Boolean equation that summarizes the patterns of causal conditions in the data for each of the outcomes of interest in QCA analysis. The following two Boolean equation summarizes the outputs of the csQCA, more specifically, the sufficient conditions for the desired outcomes:

$$
\begin{aligned}
& \mathrm{CH} \rightarrow \mathrm{O}_{4} \\
& c d f h \rightarrow \mathrm{O}_{3}
\end{aligned}
$$

Where Openness is A, Debt is B, Revenue capabilities is C, Labour movement's power is D, Strength of the left is E, Policy legacy is F, Outsiders is G, and Democracy is H. The welfare state development index is represented with an O. The results show no country with a very high WeSDI and only Uruguay with a high WeSDI. Therefore, the high and medium WeSDI are analysed together, jointly, as one desired outcome in the csQCA. High or medium welfare state development is represented with an $\mathrm{O}_{1}$, low welfare state development with an $\mathrm{O}_{2}$, very low welfare state development with an $\mathrm{O}_{3}$, and the six highest welfare state development with an $\mathrm{O} 4$.

\footnotetext{
${ }^{9}$ Following Ragin (2008), a necessary condition contains the outcome of interest while a sufficient condition must be present for the outcome to take place.
} 
Table 4: The historical experience of explanatory variables and welfare state development in a truth-table

\begin{tabular}{|c|c|c|c|c|c|c|c|c|c|c|c|c|c|}
\hline \multirow[b]{2}{*}{ Countries } & \multicolumn{3}{|c|}{ Favourable economic conditions } & \multicolumn{5}{|c|}{ Favourable political conditions } & \multicolumn{5}{|c|}{ Outcomes } \\
\hline & $\begin{array}{l}\text { High } \\
\text { openness }\end{array}$ & Low indebtedness & $\begin{array}{l}\text { High } \\
\text { revenue } \\
\text { capabilities }\end{array}$ & $\begin{array}{l}\text { High labour } \\
\text { strength }\end{array}$ & $\begin{array}{l}\text { High strength } \\
\text { of the left }\end{array}$ & $\begin{array}{l}\text { High level } \\
\text { of policy } \\
\text { legacies }\end{array}$ & $\begin{array}{l}\text { High } \\
\text { proportion } \\
\text { of outsiders }\end{array}$ & $\begin{array}{l}\text { High } \\
\text { democratic } \\
\text { strength }\end{array}$ & $\begin{array}{l}\text { Very } \\
\text { high } \\
\text { WSD }\end{array}$ & $\begin{array}{l}\text { High } \\
\text { WSD }\end{array}$ & $\begin{array}{l}\text { Medium } \\
\text { WSD }\end{array}$ & $\begin{array}{l}\text { Low } \\
\text { WSD }\end{array}$ & $\begin{array}{l}\text { Very } \\
\text { low } \\
\text { WSD }\end{array}$ \\
\hline Argentina & 1 & 1 & 1 & 1 & 0 & 1 & 1 & 1 & 0 & 0 & 1 & 0 & 0 \\
\hline Bolivia & 0 & 1 & 0 & 1 & 1 & 0 & 0 & 1 & 0 & 0 & 0 & 1 & 0 \\
\hline Brazil & 0 & 0 & 1 & 1 & 1 & 1 & 1 & 1 & 0 & 0 & 1 & 0 & 0 \\
\hline Chile & 1 & 1 & 1 & 0 & 0 & 1 & 0 & 1 & 0 & 0 & 1 & 0 & 0 \\
\hline Colombia & 0 & 0 & 0 & 0 & 0 & 1 & 1 & 0 & 0 & 0 & 0 & 1 & 0 \\
\hline Costa Rica & 1 & 0 & 1 & 0 & 1 & 0 & 0 & 1 & 0 & 0 & 1 & 0 & 0 \\
\hline $\begin{array}{l}\text { Dominican } \\
\text { Republic }\end{array}$ & 0 & 1 & 1 & 0 & 1 & 0 & 1 & 0 & 0 & 0 & 0 & 1 & 0 \\
\hline Ecuador & 0 & 0 & 0 & 1 & 1 & 1 & 0 & 0 & 0 & 0 & 0 & 1 & 0 \\
\hline El Salvador & 0 & 0 & 0 & 0 & 0 & 0 & 1 & 0 & 0 & 0 & 0 & 0 & 1 \\
\hline Guatemala & 0 & 1 & 0 & 0 & 0 & 0 & 0 & 0 & 0 & 0 & 0 & 0 & 1 \\
\hline Honduras & 1 & 0 & 0 & 0 & 0 & 0 & 1 & 0 & 0 & 0 & 0 & 0 & 1 \\
\hline Mexico & 0 & 1 & 1 & 0 & 0 & 0 & 0 & 0 & 0 & 0 & 0 & 1 & 0 \\
\hline Nicaragua & 0 & 0 & 0 & 0 & 1 & 0 & 0 & 0 & 0 & 0 & 0 & 0 & 1 \\
\hline Panama & 1 & 0 & 1 & 0 & 1 & 0 & 0 & 1 & 0 & 0 & 0 & 1 & 0 \\
\hline Paraguay & 0 & 1 & 0 & 0 & 0 & 0 & 1 & 0 & 0 & 0 & 0 & 0 & 1 \\
\hline Peru & 0 & 0 & 0 & 0 & 0 & 0 & 0 & 0 & 0 & 0 & 0 & 0 & 1 \\
\hline Uruguay & 1 & 1 & 1 & 1 & 1 & 1 & 0 & 1 & 0 & 1 & 0 & 0 & 0 \\
\hline Venezuela & 0 & 1 & 0 & 0 & 1 & 1 & 1 & 0 & 0 & 0 & 0 & 1 & 0 \\
\hline
\end{tabular}


Equation 3 and 4 represent the two paths for sufficient conditions found in the csQCA. This means that on the one hand-in Eq. 3-the simultaneous presence of comparatively high revenue capabilities and comparatively high democratic strength is a sufficient condition for outcome four (six highest welfare state development). In terms of parameters of fit in the analysis of necessary conditions in fsQCA 3.0 software (Ragin and Davey 2016), both, high democratic strength and high revenue capabilities are the only conditions with a consistency score of 1.0. ${ }^{10}$ Therefore, both of these are necessary conditions for the six highest welfare state development scores. The former has a coverage score of 0.86 and the latter of 0.75. Openness show consistency and coverage scores of 0.83 , so it could be considered a quasi-necessary condition for outcome 4 . As we can expect from the equations, the combination of high revenue capabiliti es and democratic strength show a consistency score of 1.0 and a coverage score of 0.67 .

Table 5: Is it possible to find a common path of (un) favourable conditions for welfare state development?

\begin{tabular}{|c|c|c|c|c|c|c|c|c|c|}
\hline & WeSDI & Openness & Debt & $\begin{array}{l}\text { Revenue } \\
\text { capabilities }\end{array}$ & $\begin{array}{l}\text { Labour } \\
\text { movement's } \\
\text { power }\end{array}$ & $\begin{array}{l}\text { Strength } \\
\text { of the left }\end{array}$ & $\begin{array}{l}\text { Policy } \\
\text { legacy }\end{array}$ & Outsiders & Democracy \\
\hline Uruguay & 0,7527 & + & + & + & + & + & + & & + \\
\hline Chile & 0,6899 & + & + & + & & & + & & + \\
\hline Brazil & 0,6701 & & & + & + & + & + & + & + \\
\hline Argentina & 0,6587 & + & + & + & + & & + & + & + \\
\hline Costa Rica & 0,6015 & + & & + & & + & & & + \\
\hline Panama & 0,5895 & + & & + & & + & & & + \\
\hline Venezuela & 0,5783 & & + & & & + & + & + & \\
\hline Mexico & 0,5627 & & + & + & & & & & \\
\hline Bolivia & 0,5599 & & + & & + & + & & & + \\
\hline Colombia & 0,5452 & & & & & & + & + & \\
\hline $\begin{array}{l}\text { Dominican } \\
\text { Republic }\end{array}$ & 0,5030 & & + & + & & + & & + & \\
\hline Ecuador & 0,5029 & & & & + & + & + & & \\
\hline Paraguay & 0,4910 & & + & & & & & + & \\
\hline Peru & 0,4887 & & & & & & & & \\
\hline Guatemala & 0,4820 & & + & & & & & & \\
\hline Honduras & 0,4709 & + & & & & & & + & \\
\hline Nicaragua & 0,4518 & & & & & + & & & \\
\hline El Salvador & 0,4437 & & & & & & & + & \\
\hline
\end{tabular}

Notes: A plus sign identifies countries with a score higher than the sample mean, considered in this paper as a favourable condition for welfare state development. Debt obligations are the only variable that a score lower than the sample mean is coded as a favourable condition.

Uruguay, Chile, Argentina, Brazil and Costa Rica show, in Table 5, a combined presence of comparatively high-revenue capabilities and a high degree of democratic strength. These two are necessary conditions, but not a sufficient condition, for a medium or high welfare state development outcome. Panama experienced the same combination of conditions but ended up with a WeSDI score of 0,5895 - i.e. low welfare state development. To explain the first outcome (medium or high welfare state development), we have to incorporate the quasinecessary condition of welfare institutions' policy legacies into the picture. Countries with a medium or high welfare state development experience one of the following two paths:

1. a high democratic strength and revenue-capabilities combined with a comparatively

high experience of welfare institutions (Argentina, Chile, Uruguay and Brazil)

2. a high democratic strength and revenue-capabilities combined with welfare institutions and programmes with a social-democratic universalistic-like nature (Costa Rica)

\footnotetext{
${ }^{10}$ Schneider and Wagemann (2012) recommends using 0.90 as the threshold for a condition to be considered a necessary condition, which indicates that 90 per cent or more of the cases exhibiting the outcome also exhibit the condition.
} 
There is no path of sufficient conditions for the second desired outcome (low welfare state development). However, the simultaneous absence of comparatively high revenue capabilities, labour strength, level of welfare policy legacies and democratic strength is a sufficient condition for outcome three (very low welfare state development). The lower case letters in equation 4 indicate that their negations are a sufficient condition for the outcome. Contrariwise, upper case letters in equation 3 indicate that the combined causal conditions (their presence) are a sufficient condition for the outcome. In the analysis of necessary conditions of this third outcome, low revenue capabilities, low democratic strength, low level of labour strength and low level of welfare policy legacies are the only conditions - negated in this case- with a consistency score of 1.0. Therefore, these four negated conditions are necessary conditions for the outcome very low level of welfare state development. Low revenue capabilities has a coverage score of 0.6 , low democratic strength has a score of 0.55 , low level of labour strength has a score of 0.46 and low level of welfare policy legacies has a coverage score of 0.55 . Openness and strength of the left show consistency scores of 0.83 , therefore these negated conditions could be considered as quasi-necessary conditions. As we can expect from equation 4 , the combination of low revenue capabilities, low democratic strength, low level of labour strength and low level of welfare policy legacies show a consistency score of 1.0 and a coverage score of 0.4 .

Results in the QCA were triangulated with an ordinary least square regression analysis between the WeSDI and each of the normalised composite index operationalising the eight causal conditions. Figure 1 shows the results in a scatterplot matrix. Revenue capabilities, the historical experience of social protection institutions and democracy are the only three variables with a positive, strong and statistically significant relationship - at the 0.01 level - with the multidimensional welfare state index.

\section{Figure 1: Scatterplot matrix: Welfare state development versus eight political and explanatory} variables
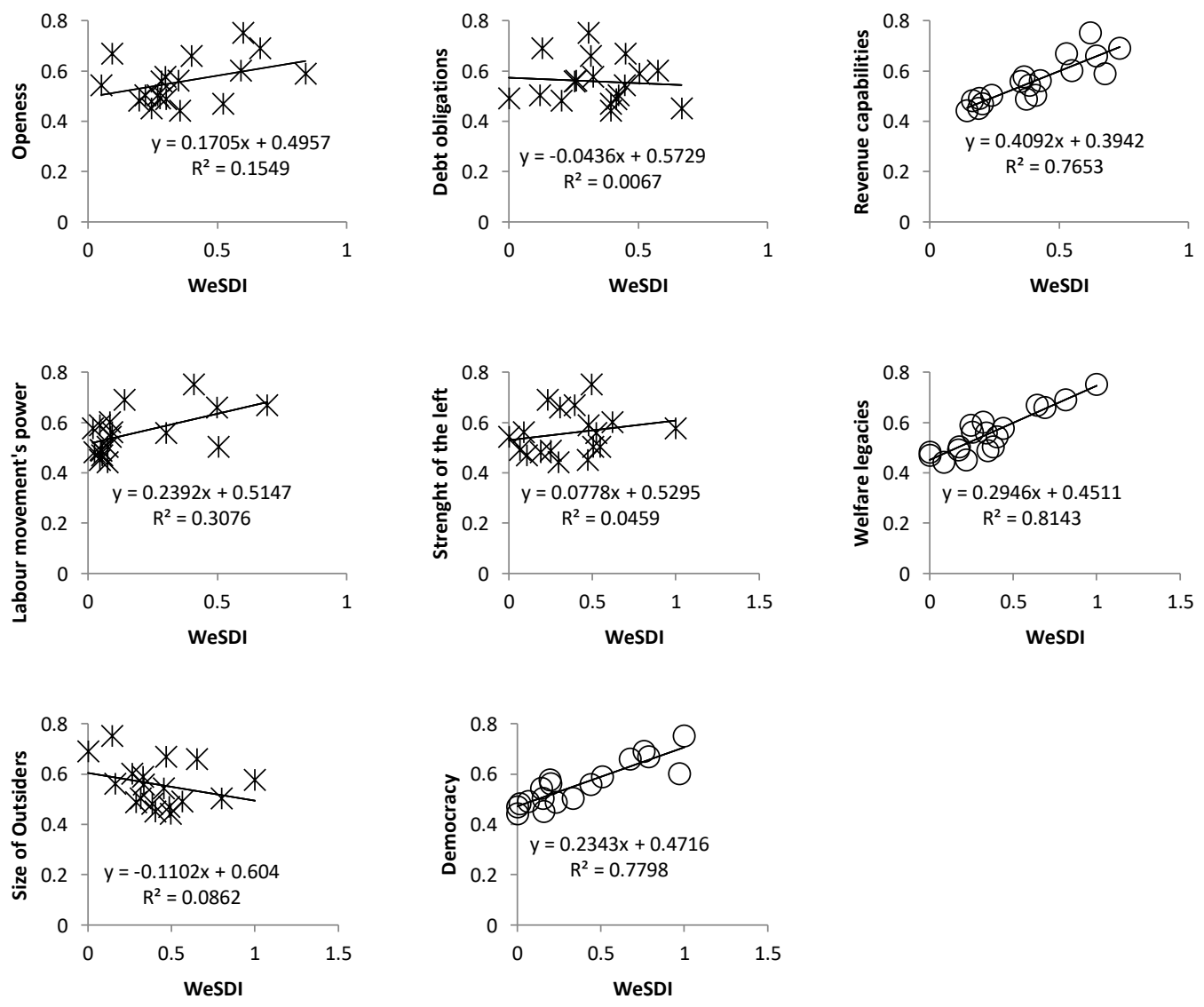

Notes: Simple linear regression between the WeSDI and the eight explanatory variables. A statistically significant relationship at the 0,01 level is shown with circles in the data range. 
For robustness check, the csQCA was also performed with different cutoff points during the dichotomization of causal conditions. Instead of the sample mean, cutoff points were adjusted to 0.5 of the normalised index operationalising the causal conditions. The robustness check showed similar results: countries with the highest level of welfare state development experienced a combination of high revenue capabilities, democratic strength and historical experience of welfare institutions - except Costa Rica that did not show a high level of historical experience of welfare institutions. In addition to the four unfavourable factors for welfare state development, Guatemala, Peru, Honduras, Nicaragua, Paraguay and El Salvador also experienced a low strength of the left.

\section{Discussion}

Uruguay, Argentina, Brazil, Chile and Costa Rica shared the combination of high revenue capabilities and strong democracies. All four except Costa Rica also experienced a long historical experience of welfare institutions (high policy legacies). This result makes logic as Uruguay, Argentina, Brazil and Chile implemented Bismarckian social welfare systems, and long historical experience enables the gradual expansion. On the contrary, Costa Rica did not require a long historical experience because they implemented a welfare system following the social democratic and universal model. According to Barba Solano (2009, p. 333):

"Costa Rica followed the Beveridge model of universal coverage. Between the 1960s and 1970s, Costa Rica was able to secure an almost universal coverage of their social protection system. In fact, the Costa Rican social security system was born unified, eluding eluded the failures of the pioneer countries and applying the principles of the ILO."

Brazil, Uruguay, Argentina and Chile had the highest fiscal burdens as a percentage of GDP. Alongside Costa Rica, they collect an average 27,3 per cent of GDP while the regional average is 20 per cent and the fiscal burden of countries with very low welfare state development is - on average - 16,5 per cent of GDP. The economic growth appears to have the least explanatory power. All cases in the region experience a positive economic growth; however, only Chile was in the top 3 with a rate of growth of 4,9 per cent, while Argentina, Uruguay and Brazil had the seventh-worst, fifth-worst and worst economic growth rates during the post-neoliberal era - respectively. Following Campello (2015) and Garay (2016), Latin American states undoubtedly benefitted from the commodity boom and high economic growth rates which allowed them to finance social protection systems. However, economic growth in 1990-2015 does not appear to causal condition to explain the different degrees of welfare state development in the region.

Uruguay, Costa Rica, Brazil, Chile and Argentina had the five highest democracy scores in the composite democracy variable, as well as in the five V-dem individual indices: electoral, liberal, deliberative, participatory and egalitarian. Uruguay and Costa Rica clearly showed the highest democratic strength of all. Uruguay shows a slightest higher score in the composite index and the participatory index, while Costa Rica tops the electoral, liberal, deliberative and egalitarian indices. The five countries had a score 43 per cent higher than the sample average, and almost doubles the score of the countries with a very low level of welfare state development $(0,74$ versus 0,38$)$.

Uruguay (99y), Chile (87y), Argentina (80y) and Brazil (77y) have the highest average historical experience of welfare state programmes, and it is mainly due to the early implementation of welfare programmes in the area of old age, disability and survivors. On the other hand, Costa Rica has an average of 56 years of experience, with Venezuela, Colombia, Ecuador, Peru and Bolivia surpassing the Costa Rican experience. Brazil, Chile and Argentina top the historical experience in the sickness/maternity programme, while Costa Rica is around the middle of the sample and Uruguay appears last. Regarding family allowances, Chile, Brazil and Uruguay are the countries with the highest years of experience. In the work injury welfare, Uruguay (second) Argentina (third) and Chile (fifth) are the best performers among the most developed welfare states. Clearly, the unemployment programs are the ones that need to be urgently developed. The vast majority of the countries do not have unemployment insurance in place, relying only on severance schemes. The exceptions are Uruguay, Chile, Venezuela, Ecuador, Argentina, Brazil, Colombia, and Honduras.

The top six countries with the highest level of welfare state development - except for Brazil - have a high degree of openness. It seems that globalisation, rather than economic openness, is more significant to understand the classification of countries in the two highest categories of welfare state development. Chile, Uruguay, Argentina and Costa Rica experienced the highest degree of globalisation according to the KOF index. On the other hand, Costa Rica was the only country with economic openness above the sample average (i.e., total trade equals 79 per cent of the GDP). Brazil exhibited an outlier experience, being the country with the less opened economy in the sample and sixth less globalised. 
A reviewer pointed out the surprising fact that Chile and Argentina are not considered to have had a strong left experience during the post-neoliberal era, especially, with the Concertación government in Chile and the Kitchener governments in Argentina. If we take a look at the indicators used - regardless of the decision of using the mean as a cut-off point - readers might confirm why these two countries are not in the strong left category:

- Seat share of centre-left and left parties in the lower house: Chile (31\%) and Argentina (18\%)

- Number of years of centre-left and left: Chile (8) and Argentina (10)

- Seat share in the lower house of the party of the executive when the left was in the executive: Argentina (39\%) and Chile (10\%)

After ordering the results of the composite indicator, Argentina ended up in the 10th position and Chile in the 13th position in relative terms of strength of the left. If the period examined in the paper were 20002015 , the strength of the left would still be neither a necessary condition nor a sufficient condition for welfare state development.

Countries with a very low level of welfare state development - El Salvador, Guatemala, Honduras, Nicaragua, Paraguay, and Peru - also experienced a similar path of causal conditions. They all experienced a combined absence of high revenue capabilities, high labour movement's power, a long historical experience of welfare institutions and high democratic strength in the 1990-2015 period. Therefore, the (un)favourability of the same three causal conditions is useful to group together countries with the highest and lowest levels of welfare state development. Also, the absence of a strong labour movement appears to be relevant to understand the low levels of welfare state development.

El Salvador, Guatemala, Nicaragua, Paraguay, Honduras have the lowest revenue capabilities of the sample. Along with Peru, the six countries with a very low level of welfare state development are in the bottom eight in terms of fiscal burden and the bottom seven regarding GDP per capita. Once again, economic growth does not appear to help us understand why these countries have a very low level of welfare state development. The six countries have a revenue capabilities score 47 per cent smaller than the sample mean, and almost three times smaller than the average for Uruguay, Chile, Argentina and Brazil $(0,62$ versus $0,21)$.

Institutionalised power resources appear to be more relevant than non-institutionalised. Nicaragua, Honduras, Peru, Paraguay and Guatemala are in the bottom six countries in terms of trade union density rates. Only 6,7 per cent of workers in countries with very low levels of welfare state development are in trade unions, while the average sample rate is 16 per cent and Uruguay, Chile, Argentina, Costa Rica and Brazil have trade union density rate more than three times higher (21,5 per cent versus 6,7 per cent). Moreover, five per cent of workers in countries with a very low level of welfare state development are covered by collective bargaining - compared to a sample mean of 20 per cent. The number of strikes and lockouts were more than three times lower than the sample mean (47 versus 151). Days not worked due to strikes and lockouts were almost 14 times lower than the sample mean, and workers involved in strikes and lockouts were almost 19 times lower than the sample mean.

The historical experience of welfare state programmes in Guatemala, Honduras, El Salvador, Paraguay, Nicaragua and Peru is almost half than the experience of Uruguay, Argentina, Chile and Brazil (44 years versus 80 years). If the early creation of old age, disability and survivors programmes is key for countries with the highest welfare state development, the absence of unemployment programmes is the main commonality of the six countries with the lowest level of welfare state development. Honduras is starting to change this, as they created the first unemployment scheme in 2015.

El Salvador, Honduras, Guatemala and Paraguay have the most fragile democracies in the region according to the composite index with V-dem data. Peru is in the ninth position and Nicaragua in the twelfth.

Finally, three additional relevant results: Costa Rica and Panama have a similar path, with the strength of the left being the only significant difference. This might be one of the reasons to explain Costa Rica's higher level of welfare state development. Second, even though the case of Ecuador shows unfavourable conditions on most of the factors, it shows a high strength of the left and a high labour movement power. This might also be pushing Ecuador up to the low level of welfare state development, instead of being in the least developed group. Third, Mexico, Colombia, Guatemala and Peru exhibited an identical path in the QCA. However, they do exhibit different results in the WeSDI. Therefore, additional causal conditions might explain their diverging welfare state development outcome. 


\section{Conclusion}

Economics and politics matter to understand why some countries in Latin America have been able to develop more than others their welfare state. This paper proposes a multidimensional welfare state development index (WeSDI) and used to test the power of three economic and five causal conditions of welfare state development during the post-neoliberal era (1990-2015).

Uruguay is the only country with a high welfare state development in the (post)neoliberal era, followed by Chile, Brazil, Argentina and Costa Rica with medium welfare state development. Panama, Venezuela, Mexico, Bolivia, Colombia, the Dominican Republic and Ecuador have a low welfare state development, and Paraguay, Peru, Guatemala, Honduras, Nicaragua and El Salvador have very low levels of welfare state development. The composite index measuring the level of welfare state development combines four dimensions of the welfare state: (i) social investment in health, education, social security and housing, (ii) coverage of welfare programmes, (iii) outcomes of welfare institutions, and (iv) quality of the coverage of welfare programmes.

QCA confirmed the existence of a shared path followed by countries with the top six welfare state development scores and countries with a very low level of welfare state development (WeSDI scores below 0.50). Uruguay, Chile, Argentina, Brazil Costa Rica and Panama experienced a combined presence of high revenue capabilities and high democratic strength during 1990-2015. Thus, the combined presence of comparatively highrevenue capabilities and a comparatively high degree of democratic strength explain the six highest welfare state development. In QCA terminology, these two are necessary conditions for having one of the top six welfare state development and its combined presence is a sufficient condition for the outcome.

Paraguay, Peru, Guatemala, Nicaragua, Honduras and El Salvador, experienced a combined absence of four favourable political and economic conditions for welfare state development: high democratic strength, high revenue capabilities, high historical experience of social protection programmes, and high labour movement strength. Thus, the combined absence of comparatively high democratic strength, high revenue capabilities, high historical experience of social protection programmes, and high labour movement strength leads to the less desired outcome: very low level of welfare state development. In QCA terminology, these four negated conditions are necessary conditions for a very low level of welfare state development and its combined absence is a sufficient condition for the outcome. Results were confirmed with ordinary least squares regression analysis and with a different cut-off point for the causal conditions in the csQCA $(0.5$ instead of sample means).

Future research must incorporate social and demographic factors as causal conditions. Do the ethnic composition, religions, ageing and other social and demographic factors have conditioned the development of welfare systems in Latin America? Besides, the dichotomization of conditions must be performed following a more theoretically driven logic, rather than an empirical and relative logic. Future research should also rethink alternative ways to measure the welfare state development outcome. In the meantime, we confirm the relevance of democratic strength, and revenue-collection capabilities as causal conditions of high and medium degree of welfare state development in the (post) neoliberal era. In addition to labour movement strength and policy legacies of welfare institutions these same economic and political conditions are relevant to understand the causes of very low welfare state development in the region.

\section{References}

Amable, B., Gatti, D., \& Schumacher, J. (2006). Welfare-State Retrenchment: The Partisan Effect Revisited. Oxford Review of Economic Policy, 22(3), 426-444. doi:10.1093/oxrep/grj025

Barba Solano, C. (2005). Paradigmas y Regímenes de Bienestar. Costa Rica: Facultad Latinoamericana de Ciencias Sociales.

Barba Solano, C. (2009). Los regímenes de bienestar latinoamericanos y la reforma social. In C. Barba Solano, G. Ordoñez Barba, \& E. Valencia Lomelí (Eds.), Más allá de la pobreza: Regímenes de bienestar en Europa, Asia y América (pp. 327-370). Guadalajara: Universidad de Guadalajara, El Colegio de la Frontera Norte.

Barreix, A., Corrales, L. F., Díaz, S., \& Garcimartín, C. (2017). Actualización de la presión fiscal equivalente en América Latina y el Caribe. Documento para discusión $\mathrm{N}^{\circ}$ IDB-DP-548: Banco Interamericano de Desarrollo.

Barrientos, A. (2004). Latin America: Towards a Liberal-Informal Welfare Regime. In I. Gough \& G. Wood (Eds.), Insecurity and Welfare Regimes in Asia, Africa and Latin America: Social Policy in Development Contexts (pp. 121-168). Cambridge: Cambridge University Press. 
Barrientos, A. (2019). Social protection in Latin America: One region two systems. In G. Cruz Martinez (Ed.), Welfare and Social Protection in Contemporary Latin America. London: Routledge.

Campello, D. (2015). The Politics of Market Discipline in Latin America: Globalization and Democracy. Cambridge: Cambridge University Press.

CEPAL. (2018a). CEPALSTAT: United Nations: http://estadisticas.cepal.org/.

CEPAL. (2018b). Panorama Social de América Latina 2017. Santiago de Chile: United Nations, retrieved from https://www.cepal.org/es/publicaciones/42716-panorama-social-america-latina2017-documento-informativo.

Coppedge, M. (1997). A Classification of Latin American Political Parties. Working Paper \#244. Kellogg Institute. http://nd.edu/ kellogg/publications/workingpapers/WPS/244.pdf.

Coppedge, M., Gerring, J., Knutsen, C. H., Lindberg, S. I., ing, S.-E. S.-., Teorell, J., . . Ziblatt, D. (2018). "V-Dem Codebook v8" Varieties of Democracy (V-Dem) Project.

Coppedge, M., Gerring, J., Knutsen, C. H., Lindberg, S. I., Skaaning, S.-E., Teorell, J., . . Ziblatt, D. (2018). "V-Dem [Country-Year/Country-Date] Dataset v8". Varieties of Democracy (V-Dem) Project.

Cruz-Martinez, G (2014). Welfare State Development in Latin America and the Caribbean (1970s2000s): Multidimensional Welfare Index, Its Methodology and Results. Social Indicators Research, 119(3), 1295-1317, doi:10.1007/s11205-013-0549-7.

Cruz-Martinez, G. (2017a). Is there a Common Path that could have Conditioned the Degree of Welfare State Development in Latin America and the Caribbean? Bulletin of Latin American Research, 36(4), 459-476. DOI:10.1111/blar.12556

Cruz-Martinez, G. (2017b). Welfare State Development, Individual Deprivations and Income Inequality: A Cross-Country Analysis in Latin America and the Caribbean. Social Indicators Research, 134(3), 955-979. DOI:10.1007/s11205-016-1465-4

Cruz-Martinez, G. (2018). A Bottom-up picture of intra-national welfare regimes: the case of marginalised communities in Puerto Rico. Journal of International and Comparative Social Policy. doi:https://doi.org/10.1080/21699763.2018.1526696

Dion, M. (2006). Globalización, tipo de régimen político y gasto social en países de ingresos medios, 1980-1999. Política y gobierno, 49.

Dreher, A. (2006). Does globalization affect growth? Evidence from a new index of globalization. Applied Economics, 38(10), 1091-1110. DOI:10.1080/00036840500392078

Esping-Andersen, G. (1990). The three worlds of Welfare Capitalism. Princeton, NJ: Princeton University Press.

Ewig, C. (2016). Reform and Electoral Competition: Convergence Toward Equity in Latin American Health Sectors. Comparative Political Studies, 49(2), 184-218. DOI:10.1177/0010414015600467

Fairfield, T., \& Garay, C. (2017). Redistribution Under the Right in Latin America: Electoral Competition and Organized Actors in Policymaking. Comparative Political Studies, 50(14), 1871-1906. DOI: $10.1177 / 0010414017695331$

Feenstra, R. C., Inklaar, R., \& Timmer, M. P. (2015). The Next Generation of the Penn World Table, 105(10), 3150-3182. American Economic Review, 105(10), 3150-3182, available for download at www.ggdc.net/pwt.

Filgueira, F. (1999). Tipos de Welfare y reformas sociales en América Latina: Eficiencia, residualismo y ciudadanía estratificada. In M. Melo (Ed.), Reforma do Estado e Mudanca Institucional no Brasil. Recife: Fundacao Joaquim Nabuco.

Garay, C. (2016). Social Policy Expansion in Latin America. Cambridge: Cambridge University Press.

Grassi, D. (2014). Democracy and Social Welfare in Uruguay and Paraguay. Latin American Politics and Society, 56: 120-143. DOI:10.1111/j.1548-2456.2014.00225.x

Graziano, P., \& Jessoula, M. (2018). Explaining Welfare State Developments: Towards a Comparative Research Agenda. Sciences Po LIEPP Working Paper(76), 1-25.

Gygli, S., Haelg, F., \& Sturm, J.-E. (2018). The KOF Globalisation Index - Revisited. KOF Working Paper, 439.

Haggard, S., \& Kaufman, R. (2004). Revising Social Contracts: Social Spending in Latin America, East Asia, and the Former Socialist Countries, 1980-2000. Revista de ciencia política (Santiago), 24, 3-37.

Haggard, S., \& Kaufman, R. R. (2009). Development, Democracy, and Welfare States: Latin America, East Asia, and Eastern Europe. New Jersey: Princeton University Press.

Huber, E., \& Stephens, J. (2016). Latin America and Caribbean Political Dataset, 1945-2012.

Huber, E., \& Stephens, J. D. (2012). Democracy and the Left. Social Policy and Inequality in Latin America. Chicago: The University of Chicago Press. 
IADB, \& CIAT. (2017). Latin America and the Caribbean Fiscal Burden Database.

ILO. (2018). ILOSTAT. Social Security Inquiry Database

Inter-American Development Bank. (2018). Sociometro-BID: https://www.iadb.org/en/research-anddata/sociometro-bid\%2C6981.html.

Jordan, E., Gross, M. E., Javernick-Will, A. N., \& Garvin, M. J. (2011). Use and misuse of qualitative comparative analysis. Construction Management and Economics, 29(11), 1159-1173. DOI:10.1080/01446193.2011.640339

Kaufman, R. R., \& Segura-Ubiergo, A. (2001). Globalization, Domestic Politics, and Social Spending in Latin America: A Time-Series Cross-Section Analysis, 1973-97. World Politics, 53(4), 553-587.

Keohane, R. O., \& Nye, J. S. (2000). Introduction. In J. S. Nye \& J. D. Donahue (Eds.), Governance in a Globalizing World (pp. 1-44). Washington, D.C.: Brooking Institution Press.

Korpi, W. (1983). The Democratic Class Struggle. Londres: Routledge \& Kegan Paul.

Kurtz, M. J., \& Brooks, S. M. (2008). Embedding Neoliberal Reform in Latin America. World Politics, 60(2), 231-280. doi:10.1353/wp.0.0015

Lamartina, S., \& Zaghini, A. (2011). Increasing Public Expenditure: Wagner's Law in OECD Countries. German Economic Review, 12(2), 149-164. doi:http://www.blackwellpublishing.com/journal.asp?ref=1465-6485

Lora, E. (2009). La Vulnerabilidad Fiscal del Gasto Social: ¿Es Diferente America Latina? Revista de análisis económico, 24, 3-20.

Lora, E., \& Olivera, M. (2007). Public debt and social expenditure: Friends or foes? Emerging Markets Review, 8(4), 299-310. doi:https://doi.org/10.1016/j.ememar.2006.12.004

Mainwaring, S., Brick, D., \& Perez-Liñan, A. (2001). Classifying Political Regimes in Latin America, 1945-1999. Studies in International Comparative Development, 36(1), 37-65.

Marcel, M., \& Rivera, E. (2008). Regímenes de bienestar en América Latina. In E. Tironi (Ed.), Redes, Estado y Mercado. Soportes de la Cohesión Social Latinoamericana. Santiago de Chile: Uqbar editores.

Martín-Mayoral, F., \& Sastre, J. F. (2017). Determinants of social spending in Latin America during and after the Washington consensus: a dynamic panel error-correction model analysis. Latin American Economic Review, 26(1), 10. DOI:10.1007/s40503-017-0053-6

Martínez Franzoni, J. (2008). Welfare regimes in Latin America: Capturing Constellations of Markets, Families, and Policies. Latin American Politics and Society, 50(2), 67-100.

Mesa-Lago, C. (1978). Social Security in Latin America. Pittsburgh: University of Pittsburgh Press.

Mesa-Lago, C. (1983). Social Security and Extreme Poverty in Latin America. Journal of Developmental Economics, 12(1-2), 83-110.

Mesa-Lago, C. (1994). Changing Social Security in Latin America. London: Lynne Rienner Publishers.

Niedzwiecki, S. (2015). Social Policy Commitment in South America. The Effect of Organized Labor on Social Spending from 1980 to 2010.

Niedzwiecki, S., \& Pribble, J. (2017). Social Policies and Center-Right Governments in Argentina and Chile. Latin American Politics and Society, 59(3), 72-97. DOI:10.1111/laps.12027

OECD, IADB, \& ECLAC. (2014). Revenue Statistics in Latin America 2014.

PAHO/WHO. (2017). Health Situation in the Americas: Core Indicators

Pemstein, D., Marquardt, K. L., Tzelgov, E., Wang, Y.-t., Krusell, J., \& Miri, F. (2018). “The V-Dem Measurement Model: Latent Variable Analysis for Cross-National and Cross-Temporal ExpertCoded Data”. University of Gothenburg, Varieties of Democracy Institute: Working Paper No. 21, 3d edition.

Pierson, P. (2000). Increasing returns, Path-dependence and the Study of Politics. The American Political Science Review, 94(2), 251-267.

Pribble, J. (2011). Worlds Apart: Social Policy Regimes in Latin America. Studies in Comparative International Development, 46(2), 191-216. DOI:10.1007/s12116-010-9076-6

Pribble, J. (2013). Welfare and Party Politics in Latin America. Cambridge: Cambridge University Press.

Pribble, J., \& Huber, E. (2013). Social Policy and Redistribution: Chile and Uruguay. In S. Levitsky \& K. M. Roberts (Eds.), In The Resurgence of the Latin American Left (pp. 117-138). Baltimore: Johns Hopkins University Press.

Ragin, C. (1987). The Comparative Method: Moving Beyond Quantitative and Qualitative Strategies. Berkeley: University of California Press.

Ragin, C. (2000) Fuzzy-Set Social Science. Chicago, IL: The University of Chicago Press.

Ragin C. (2008) Redesigning Social Inquiry: Fuzzy Sets and Beyond. Chicago, IL: The University of Chicago Press.

Ragin C. \& Davey S (2016) Fuzzy-Set/Qualitative Comparative Analysis 3.0. Irvine, CA: Department of Sociology, University of California. 
Rihoux, B. \& De Meur, G. (2009) Crisp-Set Qualitative Comparative Analysis (csQCA) in Rihoux, B. \& Ragin, C. (eds.) Configurational Comparative Methods: Qualitative Comparative Analysis (QCA) and Related Techniques. Thousand Oaks, CA: Sage, 33-68.

Rihoux, B. \& Ragin, C. (eds.) (2009) Configurational Comparative Methods: Qualitative Comparative Analysis (QCA) and Related Techniques. Thousand Oaks, CA: Sage.

Roberts, K. M. (2002). Social inequalities without class cleavages in Latin America's neoliberal era. Studies in Comparative International Development, 36(4), 3-33. doi:https://doi.org/10.1007/BF02686331

Rodrik, D. (1998). Why do more open economies have bigger governments? Journal of Political Economy, 106(5), 997-1032.

Rudra, N. (2002). Globalization and the Decline of the Welfare State in Less-Developed Countries. International Organization, 56(02), 411-445. DOI:10.1162/002081802320005522

Sanchez de Dios, M. (2015). La reforma de los regímenes de bienestar en Costa Rica, Chile, Argentina, Brasil y Uruguay. Política y Sociedad, 52(3), 661-690. doi:http://dx.doi.org/10.5209/rev_POSO.2015.v52.n3.45377

Schneider, C. Q., \& Wagemann, C. (2010). Standards of Good Practice in Qualitative Comparative Analysis (QCA) and Fuzzy-Sets. 9(3), 397. doi:https://doi.org/10.1163/156913210X12493538729793

Schneider, C. Q., \& Wagemann, C. (2012), Set-Theoretic Methods for the Social Sciences, Cambridge: Cambridge University Press.

SEDLAC (CEDLAS and The World Bank). (2018). Socio-Economic Database for Latin America and the Caribbean. Retrieved from http://sedlac.econo.unlp.edu.ar/eng/index.php

Segura-Ubiergo, A. (2007). The Political Economy of the Welfare State in Latin America: globalization, democracy and development. New York: Cambridge University Press.

Social Security Administration. (2018). Social Security Programs Throughout the World: The Americas, 2017. https://www.ssa.gov/policy/docs/progdesc/ssptw/2016-2017/americas/index.html.

Sullivan, R. (2010). Labour market or labour movement? The union density bias as barrier to labour renewal. Work, Employment \& Society, 24(1), 145-156. DOI:10.1177/0950017009353660

Tanzi, V. (2002). Globalization and the future of social protection. Scottish Journal of Political Economy, 49(1), 116-127.

Tanzi, V., \& Zee, H. H. (2000). Tax Policy for Emerging Markets: Developing Countries. National Tax Journal, 53(2), 299-322.

UNDP. (2018). Calculating the human development indices-graphical presentation. Technical notes, 2018 STATISTICAL UPDATE: http://hdr.undp.org/sites/default/files/hdr2018 technical notes.pdf.

Wallerstein, M. (1989). Union organization in advanced industrial democracies. American Political Science Review, 83(2), 379-401.

Wilensky, H. L. (1975). The welfare state and equality: Structural and ideological roots of public expenditure. Berkeley: University of California Press.

World Bank. (2018a). ASPIRE: The Atlas of Social Protection Indicators of Resilience and Equity.

World Bank. (2018b). World Development Indicators. Washington, D.C.: http://data.worldbank.org/products/wdi (version 28/08/2018).

Zarate Tenorio, B. (2014). Social Spending Responses to Organized Labor and Mass Protests in Latin America, 1970-2007. Comparative Political Studies, 47(14), 1945-1972. DOI:10.1177/0010414013519409 